\title{
Is living the gender contract really a free choice? \\ A cross-national comparison of preferences or constraints in mothers' and fathers' participation in paid and unpaid work
}

Yildiz Olsson

\begin{abstract}
This article is a cross-national study of the work-family balance in families with dependent children. The countries included are Denmark, Hungary, Italy and the UK. The article aims at investigating the question "why" we still, in all four European countries, seem to live according to a traditional gender role pattern in the division of paid and unpaid work, despites mothers' entrance on the paid labour market. Women still bear the main responsibility of unpaid work. With preference theory as a starting point, the paper investigates preferences and constraints in relation to mothers' and fathers' work- and family lives. The paper relies on qualitative interviews. By using qualitative interviews, the analysis is based on fathers' and mothers' articulation of their work-life balance. The design of the interview guide has been inspired by Prue Chamberlayne's biographical methods. Thus, the analysis is based upon both fathers' and mothers' personal (life) stories in the four countries.
\end{abstract}

Key words: gender roles; paid and unpaid work; work-family balance; preferences; constraints

Please cite this article as:

Olsson, Y. (2012). Is living the gender contract really a free choice? A cross-national comparison of preferences or constraints in mothers' and fathers' participation in paid and unpaid work. Qualitative Studies, 3(1): 1-21.

\section{Introduction: Gender inequality in paid and unpaid work}

Did you know?

More than one in four women work part-time and nearly three out of four part-time jobs are held by women. Part-time work by women increases when they live with a partner and increases still further if they have dependent children. Men tend to work longer hours than women in paid employment, but women work more hours in unpaid activities - housework and caring for children and elderly parents.

\section{OECD Brochure 2006, Women and Men in OECD countries}

Although recent developments show that within the last 40 years the inequality in paid work between men and women has declined, and that a substantial number of women have entered the labour market in Europe, we have not yet seen a similar decline in the division of unpaid work. Woman still bear the main responsibility for the family- and household obligations, by which they have now acquired a double role. Contrarily, men are still viewed as the breadwinners to a far greater extent than women (Crompton et. al., 2007; Lewis et. al., 2008 and Plantenga and Hansen, 1999; Esping-Andersen, 2009). According to different European timeuse surveys, mothers in all European countries spend most time at home and on care obligations. The fathers spend most of their time on paid work (Danish Time Use Survey from 2001, Deding \& Lausten, 2004; Bonke, 2002; OECD, 2002, EUROSTAT, 2004). Despite formally recognised gender-neutral rights, gender inequality persists in practice, particularly with regards to the division of unpaid labour (Lewis et al., 2008; Lister, 2003). 
This article aims at investigating the question why we still, in the four European countries included in this article, Hungary, Italy, Denmark and the $U K$, seem to live according to the traditional gendered pattern in the division of paid and unpaid work. The paper takes its point of departure in a historically rooted gender contract that has been reproduced for generations and asks if the gender contract reflects a truly free choice, or if it is possible to break out of this pattern? The gender contract has been formulated by Carole Pateman who describes how society is still divided into the private and public sphere (Pateman 1988; Lister, 2003). The gender contract is synonymous with a traditional - Parsonian - gender division of men and women in paid and unpaid work, i.e. in the public and private spheres, respectively.

\section{Truly equal participation in practice - my normative framework}

The paper focuses on the question of preferences or constraints in paid and unpaid work. It discusses the matter of truly equal opportunities. These are not only seen as gender neutral rights, which we to some extent have acquired, but it is also asked how they have been implemented in practice. Here the question of preferences or constraints becomes crucial. According to Fraser, we need to be aware of personal preferences and the constraints to it, in order to develop political strategies that can take these constraints into account so that mothers and fathers are not restricted by external social and institutional structures. Thus, truly equal opportunities also mean truly equal opportunities in practice, where barriers such as gender specific expectations towards the particular positions of men and women are removed or overcome so that both mothers and fathers can act according to their real preferences. Following Fraser, we therefore must come up with policies that take these particularities into account in order to secure real participation in parity, also called the state of a truly equal status of citizens. Lister has developed this approach and discussed the interaction of the private and public spheres. Lister argues that policies must intervene actively in the private sphere, i.e. in the internal dynamics within in the households, otherwise ruling gender norms and gender specific expectations will dictate the positions of mothers and fathers. Thus, Lister argues that formally gender neutral policies will be gender stereo typed in practice, since such formally gender neutral rights do not differentiate between genders. If policies do not intervene in mothers and fathers' particular positions, historical gender norms will determine their position, she argues. Therefore, this article aims at illustrating the behaviours of mothers and fathers on a micro-level basis. What are their preferences and do they really seem constrained from culturally rooted gender norms and expectations towards gender roles? To what extent are they dictated by this and thus to what extent are policies necessary in order to influence this circle of reproduction of gender norms and to achieve a greater extent of participation in parity?

\section{Theoretical perspective}

Catherine Hakim (2002) has argued that mothers and fathers have a truly genuine choice when coping with the work-family balance and when deciding on the division of labour. Work-family balance is understood as managing the cross-pressure and time-squeeze of work, family- and care obligations (Lewis et. al., 2008). Based on a 1999 national survey in Britain, Hakim finds that mothers have truly free choices when deciding their household strategy. According to Hakim, women's heterogeneous employment patterns can be classified into three distinct types of women, where different types of mothers give different amounts of priority to paid and unpaid work (Hakim, 2002). Hakim distinguishes between the home-centred, work-centred, and the adaptive lifestyle. Her survey, she argues, confirms that lifestyle preferences are a major determinant of fertility, employment patterns, and job choice. External constraints in the form of institutional and cultural structures play only a minor role (Hakim, 2002). Women living the 
adaptive lifestyle combine the work and family obligations, trying to give it the same amount of priority. Most women, Hakim explains, would be found in this category. They often find jobs that can easily be synchronised with having family obligations such as jobs in the public sector or part-time jobs. In this context, the public sector is to be understood as the service and care sector which is characterised by fixed working hours and the possibility of taking part-time jobs. Hakim exemplifies this with the school teacher. The work-centred woman is the career planner and gives the most priority to paid work. This type of woman fits her family around the work. Few women are work-oriented, whereas, not surprisingly, most men are. Contrarily, many women are home-oriented meaning that they give priority to the family. As mentioned, most women live the adaptive lifestyle.

As Hakim points out herself, this theory is controversial and has been questioned and subject to much dispute since then. Other theorists such as Gash (2008), Himmelweit and Sigala (2004), Lewis et al. (2008), Gornick and Meyers (2003), Crompton and Lyonette (2006), Haas et al. (2006), McRae (2003), Esping-Andersen (2002 \& 2009), Kröger and Sipilä (2005) stress the importance of the institutional and cultural framework. McRae has taken the theory of Hakim at face value and analysed whether it could hold true. In opposition to Hakim, she, in a longitudinal study, only found little evidence for the Preference Theory. She did not find any strong distinction in preferences and attitudes between work-centred and adaptive women nor between women living the family-centred or adaptive life style. Thus, McRae found that not only attitudes and preferences were influencing the choice of lifestyle (McRae 2003), but also that women are forced to sacrifice the career in order to bring up their children and fulfil their domestic work, meaning that they are not at all liberated from constraints in the form of expectations towards the gender roles. She draws the conclusion that choices also reflect external constraints. Behaviour is not always a reflection of real personal preferences but also takes the conditions and opportunities available for a family into consideration. Additionally, qualitative studies have supported the importance of individual attributes, attitudes, labour market structures and institutions (Himmelweit \& Sigila, 2004; Kröger and Sipilä, 2005).

\section{Method}

This article will analyse the question of preferences or constraints from a qualitative and microlevel perspective. The qualitative data have been a priority, because they, in contrast to the quantitative data, give access to nuances behind the fathers' and mothers' behaviour. The article encompasses in-dept interviews with families with children from each of the four countries, Hungary, Italy, the UK and Denmark. I include four interviews from each country comprised of two from mothers and two from fathers. Thus, the four respondents are from four different families. The mothers and fathers have been interviewed separately, thus the analysis represents four families per country. The interviews have been carried out and transcribed in connection with the WORKCARE project involving eight EU Member States and chaired by Claire Wallace, Aberdeen University. The paper relies on the qualitative interviews from four of the WORKCARE countries. By using qualitative interviews, the analysis is based on the articulations of both men and women of their work-family balance. Inspired by Prue Chamberlayne's biographical methods, the analysis is based upon parents' personal (life) stories. The interviews have been carried out on the basis of the same interview guide. In the selection of the families, the aim has been to cover different family types and families with different educational backgrounds. The strategy of analysis is based upon the topics developed and included in my previous studies that included other families from the same WORKCARE sample (Olsson, 2011 \& Olsson and Boje, 2011). 


\section{Selection of countries}

The selection of the countries has been based upon Boje and Ejrnæs' classification of family policy regimes (2010). The typologies investigate how compatible and effective different family policies have been at improving conditions for combining work and care responsibilities in practice. The classification has been developed on the background of the four variables: 1) Childcare among children aged 0-3 as a percentage of the total number of children in this agegroup, 2) Effective parental leave in weeks, 3) Female part-time employment rate according to the EUROSTAT definition - self-declared part-time, 4) Total spending on family policy in percentage of GDP (Boje and Ejrnæs, 2011). Based on these four variables, it has been possible to cluster the EU Member States. The clusters are as follows:

1) The extensive family policy model (Denmark, Sweden, France and Belgium)

2) Short leave part-time model (UK and the Netherlands)

3) The long leave part-time model (Germany, Austria, Luxembourg),

4) The family care model (Italy, Spain and Portugal)

5) The extended parental leave model (Hungary, Poland and Czech Republic plus Lithuania and Finland).

This paper includes countries that represent clusters 1, 2, 4 and 5: Denmark, UK, Italy and Hungary.

\section{Results}

Cultural constraints - gender norms

In the interview guide from the WORKCARE project, I have focused on the sections, household and children, household tasks and discussions with partner. In my previous articles, I have focused on the same sections and developed the themes (Cf. Olsson, 2011 \& Olsson and Boje, 2011). In relation to this article, I have carefully gone through the themes developed in my previous two articles and have been looking at issues on preferences and constraints. Thus, I have made some conclusions as to whether the labour division in paid and unpaid work reflect a real personal choice or constraints. My overall conclusion is that mothers are constrained by the family and fathers are constrained by paid work. This article focuses primarily on how both mothers and fathers seem to be dictated by gender norms such as gender specific expectations. Despite realising that constraints and the parents' framework of opportunities are not only shaped by gender norms, but also in interaction with a given institutional framework in the form of family policies, this article aims at outlining how gender culture also contributes to shaping mothers' and fathers' choices in paid and unpaid work. Thus, the following analysis has found the themes: mothers are constrained by the family and fathers are constrained by work. The article is structured around these themes. This analysis has only been focusing on the structural constraints, which are expressed in the form of gender norms. The article does not focus on institutions and the political framework that may impact and prevent gender norms from being too dominating. Institutions may take gender norms into account and overcome these social barriers, but this article focuses on how the gender norms - the gender culture and the contract - also have an effect on families' behaviour, where the aim is to contribute to a knowledge base that institutional political strategies can be developed upon.

Mothers are constrained by the family

Mothers are left with the biggest work-family conflict. By conflict, I mean that mothers have to synchronise the demands of both paid and unpaid work; they are not just met with demands from paid work. Women are doubly burdened, where the unpaid work becomes a constraint for 
women's free choice of behaviour, including their request of being active in the labour market.

In Hungary and Italy, we find little or no conflict in the division of paid and unpaid work, meaning that mothers in these countries seem to be the ones who are complaining least about the dilemma of occupying both paid and unpaid work. Especially, mothers in Hungary were characterised by a greater acceptance of the gender division (Olsson, 2011). This means that they express fewer frustrations and reflections and thus initially seem to have fewer constraints. This interpretation is ambiguous; does it reflect a satisfaction with and an acceptance of the gender order and thus a real freedom of choice or is it merely an expression of a more rooted gender order that is so rooted that it is not questioned? In the case of the latter, the gender order is due to historically rooted gender norms - conceptualised by the historical gender contract. Furthermore, the gender order has been maintained with a lack of institutions, i.e. family policies that could have impacted opportunities and thus behaviour. Much sociological research has highlighted the fact that welfare policies have a crucial impact on opportunities and thus the behaviour and choices of mothers and fathers in paid and unpaid work. Much welfare state literature has highlighted research on how different welfare states and welfare policies impact on individual behaviour. In relation to this, different welfare state typologies have been developed (Esping-Andersen 1990; 1999; Wall 2007; Pascall and Lewis 2004; Boje and Ejrnæs 2011).

One Hungarian mother argues for fewer working hours now that she has two children. The children need to be taken care of, and it is her responsibility and thus her work-family dilemma. Constrained by gender norms, she is the one to prioritise unpaid work:

"While it was only Vivi, the two shifts were ok, but now it is both of them and Vivi going to school, I will have to try doing only one shift" (Hungarian mother 1, locksmith).

It appears that she fits her work around the family. This is despite the fact that she very much likes her job and wants to work, and, as proved by the quotation above, she was also working before having two children, and she likes her work:

Q: "If you had the opportunity, would you change anything in connection with your job and the time you spend with work?

A: I do not think so. I like doing it".

This mother is happy with her work and her colleagues:

"I love them. We love one another very much, they are nice. We get on really well. Almost everyone is older than I am, mostly middle aged women. I like talking to them, I miss them. I cannot wait to go back to work" (Hungarian mother 1).

Thus, she would want to work, but has to prioritise the children, due to her responsibilities. Choosing to work less is not necessarily a free choice since it is followed by some latent frustrations. Despite her acceptance of the gender division and her having to work less, there is a latent frustration. This frustration can be interpreted as a reflection of the rootedness of the gender order:

"It would be better if daddy spent more time at home but he has to work" (Hungarian mother 1, locksmith). 
This supports my argument of her preferences being a result of some cultural constraints and gender norms. I shall argue that the constraints consist of her having no other alternatives. She is adjusting herself to external constraints; expectations of her being the caregiver result in her preferences of wanting to work less.

Hungarian mother 2 has also chosen a job that may give her some self-realisation - as a journalist. However, her partner, who is also a journalist and who is working 12-14 hours a day, makes her choose to work less, since it is her that is responsible for the care obligations. Before having their child, she had a lot of responsibility at work:

"I was working 16 hours a day doing different things as a forced entrepreneur; I was running from one place to another" (Hungarian mother 2, journalist).

Evidence shows that this family is in a financial constraint that forces her to work so much. Despite this, she sees the household obligations as her responsibility:

"I never grumble that he doesn't do the dishes. I think that's my responsibility".

Thus, it is an expectation and a matter of course that she does the housework. Despite her frustrations, too, she quickly accepts that this is a natural division; she is asked if she is satisfied with the household strategy:

"Of course not. But if you take into consideration that he works himself to death, then I'd say that it's fair. I have to take a little more" (Hungarian mother 2, journalist).

She accepts the division of labour because she has to, but, more latently, it appears that she is not fully satisfied with it. Not being satisfied reveals her practices as an outcome of external conditions and constraints rather than a truly free choice. Her preferences have been adjusted the gender norms, by which the gender norms have become a constraint. She adjusts her preferences according to his job and his role. Moreover, Hungarian mothers are worried about finding jobs when having children and when they get pregnant. Being worried indicates dissatisfaction with this role and practices:

"Look, it would be nice for starters, that a woman shouldn't get a shock that she is pregnant and find ways to hide the fact that she is pregnant from her boss" (Hungarian mother 2, journalist).

This woman was also fired when she was pregnant, which she does not find satisfying either; it implies that giving up her work was not a real preference. Being worried about their jobs when they become pregnant indicates that expectations towards her as a care giver become a constraint for the working mother. Fewer conflicts and acceptance of the gender roles thus reflect a rooted gender contract. Otherwise, these latent frustrations would not have been the case.

Hungarian father 2, who is a driver for a storehouse, also argues that the work place should be more tolerant with mothers: his quotation underscores, too, the role and expectations of the mother:

"First, mothers should be helped more with work places that allow them to spend more time with 
their children" (Hungarian father 2).

This implies that children are still the mothers' responsibility. These mothers would want to work, but accept the gender division after having had children, due to gender expectations. Trying to apply the lifestyles, developed by Hakim, it does not seem that these mothers can choose entirely for themselves. Rather, they must adjust their choices to their circumstances, including labour market expectations, the role of the father and financial constraints. Being forced to work prevents them from living the adaptive lifestyle or the family oriented lifestyle. It seems that the Hungarian mothers must live out a fourth type of life style, which is a combination of full-time mother and full-time earner/breadwinner. And it does not seem to be a result of a truly genuine free choice.

The first Italian mother, who works part-time in a prison, is well-educated and has a Masters degree in political science. However, she expresses a request of wanting to work part-time or not at all. Choosing part-time or no working hours fits very well with expectations of her as the caregiver. The fact that this preference stems from expectations appears from the following quotation. Trying to go against these expectations towards the mother role puts her in a dilemma:

"It was hard for me because I felt like the only mother who worked and was obliged to send my daughter to school full-time because among 28 only two went full-time and all the others went to school by modules." (Italian mother 1, teacher in a prison).

This highlights a certain mother discourse. The second Italian mother, whose profession is a school teacher, was convinced that she couldn't work full-time combined with being married which, according to her, is equal to having children. And her worries seemed to become real, too; her partner is working as a mechanical engineer, and is away during the week from Monday to Friday. Thus, she has chosen to become a teacher which 'is a job that she can combine with her care obligations':

Q: "So you've always chosen a job that was easy to reconcile with family life?

A: Yes, an easy job to reconcile with family life because I was already thinking, how can you cope with a child, the house and the family? It seemed to be the simplest solution because you work half a day; and even half a day has its problems, I don't know how a woman can work a whole day, because sometimes, when there are meetings to attend, parent-teacher meetings, assignment of the term's marks, it's a disaster for me" (Italian mother 2, school teacher).

It seems that she takes it for granted that she must sacrifice work over care obligations. Not only is she living the adaptive lifestyle where she gives the same amount of priority to both the family and work, but she has been forced to living the adaptive lifestyle since she is the only person that is expected to take care of the family. Her lifestyle is not at all a mirror of her truly genuine preference, as Hakim would claim. This is a clear example of a constraint. She feels constrained by his work and thus by only having to take care of the children:

"I'd like to have another child but the problem is that my husband is transferred for work and he comes at the weekends, I'm on my own and I'd have to work altogether: with two children..().." (Italian mother 2, school teacher).

The Italian families indicate very little conflict in their household division, too, although the 
conflict is a little more outspoken than the ones observed in the Hungarian interviews. Among the Italian interviewees, we only find small steps towards a more challenged gender contract. Expectations of the mothers being the main care giver quickly make the women solve the conflict by working less, and they very quickly accept the situation and the labour division.

The first British mother had help from the father, when the children were little:

"yeah, the children yes; he was very helpful when they were babies, because it's quite hard as they are twins, so we would take turns as to who gets up at night. He would change nappy.. he'd do everything" (UK mother 1, waitress part-time).

This could, though, be due to them having twins, which demands more care compared to only having one child.

"I am happy with that because I look after the children rather than anyone else..().. I wouldn't trust anybody else properly because you hear stories about certain places, so I prefer that me and dad look after them".

There is a norm here telling that little children should only be looked after by the mother, meaning that this value or norm becomes a constraint or at least something that keeps mothers at home. It has to be noticed that she mentions that both her and dad should look after them and not necessarily only her. However, the outcome is her choosing to work part-time, and he works full-time. Her work is fitted around her family. Working part-time is an opportunity in the UK:

"I don't think it's too bad. I 'quite like the situation... I know when they start school which is 93.15, you know, the primary one, so then you can get a job during the day while they are at school, say 10-2 and this is what I used to do for a while before as well".

Q: So you would adapt your working schedule according to?

A: yeah yeah".

Despite him being involved when the children were little, she experiences conflicts and the work-family dilemma over her double burden. There are situations where she would like him to be more involved in the care-role, indicating that there still are some frustrations for her:

"I just tell him: get up! Sometimes I lay there and say: who is getting up first? But it doesn't work much" (UK mother 1, waitress).

The gender division has been reproduced again. This mother also likes to work:

“(...) I just like having my own independence, that's why I have like, I have a job as well; I don't suppose I would really, I would really have to work; it wasn't forced upon me, it was just my choice to do it".

In this case, she wants to work, and one can argue that institutional opportunities such as the provision of the part-time jobs has made this possible for the women. Using the terms of Hakim, one could argue that this mother has an adaptive lifestyle. However, one must also remember that living the adaptive lifestyle is only the case because they have the opportunities. In this case, she can work part-time, which is very common for women in the UK. In this 
context, I shall highlight how institutions contribute to choices of behaviour as well. The UK labour market is characterised by a high level of part-time jobs (short part-time). This was not the case in Italy or Hungary. Again, her lifestyle also reflects external opportunities and conditions.

The second mother was working full-time when the child was small, but she had to stop after six months:

"I did it for six months and then I thought, it was not worth it... I had to keep my daughter first and that was the best thing I ever did" (UK mother 2, student).

Six years later after having had a second child, she went back to college, and the nursery fees were paid by the college. This became possible because the partner was working part-time in the nursery back then from 9-12 p.m.

"I went to college last year. I think she was six or seven when I went back to college and my son, he was one at that time, and he went to a private nursery... and my husband was actually working at the nursery at the time and he went part-time from 9-12".

Had the family not been provided with these institutional opportunities, the gender norms would probably have dictated the gender division. As mentioned, she, for example, had to stop working when the child was little. The partner was working part-time and more involved compared to the other British fathers from the same sample that I have presented in previous articles (Olsson, 2011; Olsson and Boje, 2011). Moreover, the last sentence in the following quotation also tells us that this is not a usual thing for a British father to do:

"so if I am working he would do everything that I normally do... and he is doing quite good that was (laughs) he would do the cleaning and cooking... he is a chef anyway, everything that I normally do... and he is doing quite good that... he needs to do as much cooking as possible at home because I just cannot cook. he is really good in that way...bathing them and brushing their teeth and things... he is quite switched on because a lot of men would just leave them (UK mother 2, student).

This father has actively chosen to have more time with his family, and thus he has been working against the general norms:

"I think that he would be spending more time with the kids because he was working full-time and he cut down to part-time and the only reason was to be more with them... because he is working as a chef and they did offer him working full-time or part-time. I think he still could if he wished to do so, but I think as long as this gets food on the table and the bills paid because sure the kids are important".

This family does not seem as much constrained as some of the others. With her being able to go on with her studies and him working part-time, they are able to reorganise their household strategy according to their needs and preferences. They have more free choice and have been acting against the more traditional gender values, meaning that they also have been acting against the gender contract by the father transcending the private-public sphere. I conclude that they are acting against what is generally the norm in the British culture on the basis of her referring to their collaborative strategy as being unusual. Both cases indicate a weaker gender 
contract, especially in the second case where his participation at home has been more persistent. Both families illustrate an example of a work-family dilemma being solved by a more collaborative household strategy, which the mothers seem to appreciate, since it also appears that they wanted to work and to study. However, they also noted that this involvement from the fathers and co-operation was very unusual for a British family. The conflicts are reduced because the families have had a more co-operative strategy that fulfils the needs of both the mother and the father. In this case, we find that institutions also have an impact on their behaviour. Flexibility and the opportunity of working part-time give these families a freer choice, despite still being dictated by the gender norms as well.

In Denmark, the first mother is a housewife. This is a very unusual family type in Denmark today. In this family, the fathers' job and the importance of it becomes a constraint for mother. She liked working, but, in her case and with his job, having children has put her in a double role and in a work- and family dilemma:

Q: "How was your experience with paid work?

A: I thought it was exciting. I also got the education as a bailiff through my work. That was very exciting. But having children makes you vulnerable" (Danish mother 1, housewife).

She adapts her lifestyle according to him:

Q: "How does his job affect your family life?

A: His previous job as a managing director at XXX affected us very much. He was always travelling and away. He never made his plans to fit our family life. It was always the other way around; us having to adapt to his job and his meetings, etc".

One could argue that this is a free choice of this mother since Denmark in general is not characterised by such a family type. However, one could also argue that in choosing this life, despite liking working, is a reflection of her gender values. She reflects some more traditional gender values. She supports the fact that she should be at home and him being the breadwinner, and that work is more important to him. However, it may be questioned whether she could choose differently. The answer to this is no, I shall claim. Not with this man, since he also lives according to a strong traditional gender contract. She gives up her job, not because she necessarily really wants to - this is at least not what she is saying - but because she could not cope with a paid job now that she is the only one to take care of the children:

"After the leave with Anders (the youngest of the boys), I worked for one year, and then we moved to Munich. And giving up on my job was actually fine with me. It was hard working when you know that your husband isn't able to help out at all; often, he was away on business trips. I could never call him, for example, when the children were sick. But that was a choice of our own. We decided that he was the one going on with the career so I never questioned the way of organising it and the fact that I was alone in taking care of the children"(Danish mother 2, housewife).

She adapts the situation and accepts the conditions due to having no alternatives:

"I mean, if you are not used to having your husband at home and nursing you, then you don't expect him to be there afterwards. My friends have asked me of what I have thought about him being so absent but I have also been used to being alone with things so I didn't expect him to be there". 
This mother sees this as a free choice, despite concluding that she does not seem to have other alternatives due to his situation and him living out the traditional breadwinner role. Thus, I shall argue that the choice of this housewife might be a free choice for her. But seen from the perspective of the researcher, it reflects an accommodated preference; giving up her job, despite reflections, reflects a constraint, due to lack of alternatives.

Danish mother 2, who is a shop assistant, also finds her husbands' work a constraint. She argues that it was better when he was working less, meaning that they could work together on the careand household responsibilities: they have tried to reorganise things, but it has not changed, also not when she complained about her double burden and sole responsibility at home. Her situation does not stem from a genuine free choice, either.

Q: "Do you ever talk about reorganising it?

A: Yes but it doesn't change..(). Well, sometimes we have different ways of perceiving things and the amount of work, and if I were to complain, it wouldn't change anyway"

In this case, the gender contract is being challenged but it is still quite rooted in practice. It is still difficult to erode the dictating gender norms. According to her, a real preference would be a more collaborative strategy. Her complaining also indicates that her lifestyle and household strategy is a result of some external constraints.

Fathers are constrained by work

This section aims at illustrating how fathers are also constrained by gender norms, which in their case is the breadwinner role. It thus aims at addressing how gender expectations are not towards the role of the mother only, but also towards the role of the father. Furthermore these expectations towards the role of the fathers, which are also seen from the labour market perspective, constraints the mothers even more by putting more pressure on her to take care of the family obligations. This starts a circle that contributes to upholding the expectations towards the father role. Thus, we find that both parents are constrained by living according to the gender contract. This sequence aims at addressing what the fathers have said.

Hungarian father 1 has a family with very traditional gender roles; she runs the household, and he is the breadwinner. Having a job is a condition for running a family, and he is seen as the breadwinner:

"I mean if you give up your job then you can't support your family".

This clearly indicates what he thinks is expected from his role. In contrast to the mother, he is constrained by his work. He feels pressure, and his work-life conflict does not come because of the family and his children but because of his breadwinner role and his position at work:

"Well, I'm pretty satisfied, but I hope others are also. I mean, if I don't do my work well, then I feel huge remorse" [...]

Q: “Can you relax?

A: Well, it's not because of them (the children), it's because of my work that I can't. I work as an architect, and I draw a lot in the night. So because of that. So I'm sometimes tired and sleepy" (Hungarian father 1, architect) 
The wife has been on leave for seven years which may put even more pressure on him, financially. He has not been reflecting upon any alternatives. His role is a matter of course and pre-destined. However, the rooted gender contract results in no reflections and request of wanting things to be different. The work is also very important to the second father (the fourth family). He has to work in order to provide for the family. When he is asked if he wants to work less, he answers that according to the circumstances; he has to work. His preference is given due to circumstances and gender roles and gender expectations and not something that he has been reflecting upon.

Q: "Given the choice, would you rather have more time at home or a larger salary?

A: Unfortunately, it shifts to a larger salary, as it doesn't matter that I can have more time at home if we cannot afford things" (Hungarian father 2).

But he is not necessarily satisfied, despite not questioning the situation:

Q: "Do you feel that this is the way you want to balance work and care?

A: No, unfortunately not. I have to work a lot mostly because of financial reasons".

He is constrained by his breadwinner role, and would like to work less but it is difficult to change the situation:

"Yes, shorter work time probably would help. Well, my wife cannot work because we have little children and Csabi will start school. He will need more help in learning. It would be hard to get a half-job, and she cannot work full-time. It is very hard to change this situation", and" it is a bigger responsibility (after having children, ed.) and I have to appreciate the work I have".

Lack of other alternatives too, indicates that his behaviour reflects external conditions and constraints. He indicates that it is a matter of course that she is in charge of the care obligations, and having children gives him a greater responsibility as a breadwinner. He likes his job, but it is sometimes stressful, too. He accepts it, despite a latent frustration:

"I love to do my job, but it often gets on my nerves. It is stressful".

This means that a real preference and a better balance for him would be to have less work pressure. Thus, one could argue that a collaborative strategy would ease his burden, too. However, this alternative is not even close to being recognised or reflected upon, which is to be explained by the rooted gender norms.

The first Italian father, who is a hospital doctor (his wife is a doctor, too, but she works parttime after having had children), also feels pressure around his work. This father had no concerns about having children:

"so if we had to compare the two things, work is definitely more a source of stress while my family is a source of ..(sentence not finished ed.)" (Italian father 1, doctor)

And he has not experienced changes in his life style after having children:

"No I just went back to normal". 
When one of the children was little, he, however, had night shifts so that he could take care of the child during the day.

This father does find it important to spend time with the family and children had it not been for his work pressure:

"The biggest difference is having to organise your time to make sure you can dedicate a minimum...I mean, it's got to be more than the minimum really because you realise that the relationship with your children is built on time. I mean, the quality is important but so is the quantity" (Italian father 1, hospital doctor).

This also indicates a dilemma for the father. He tries to find a better work-family balance by cutting down on working hours, however, it is difficult which supports the fact that it is a constraint in the form of gender role expectations ruling in the labour market. Thus labour market structures are also build around gender norms that in this case dictates a father's greater responsibility in paid work:

"No, I tried to compromise. I realised that things had reached a critical point, and I took a step back and rethought things, I tried to streamline my responsibilities at work. Also because, when it comes to your family, you don't get a second chance. You can't make up for lost time later".

A real preference for him is to spend more time with the family:

"No, I'd like to have more time (to play with the children, ed.), it would make me happy" (Italian father 1, hospital doctor).

Thus, his constraints are not around the family as is the case for the mothers but around work; gender norms have traditionally dictated fathers into the paid work - the public sphere and the breadwinner role, which often results in larger paid work responsibilities for fathers than for mothers:

Q: "So then if arguments arise every so often, they generally tend to be about whether you spend enough time or not with the children?

A: Yes about coming home late and so on, that's probably the only thing" (IT father 1, doctor).

Indirectly, we get access to the partners' real preference; to have the husband more at home with the family.

The second Italian father - the fourth Italian family - does not question the labour division, although it creates conflicts with his partner. They have a clear gendered labour division, which makes his wife complain about his lack of involvement at home. They clearly always argue about their housework duties:

Q: "And you never argued about any problems you may have had regarding your housework duties?

A: Yes yes yes, of course, always" (Italian father 2).

This underscores the fact that his role is a constraint for her, and her frustration indicates that 
her role does not entirely stem from a truly genuine choice. His lack of reflections and questioning indicates an example of a more rooted gender order that still has its dominance. He sees himself as the head of the family: "I am the head of the family", and he does not expect it to be different: "I am very satisfied with this". One could expect that this moreover would create some tension at home now that the wife is not satisfied with the situation.

The case of Italy is ambiguous. One father clearly expresses that a real preference would be to spend more time with his family. He feels constrained by his work pressure and work responsibility. He, too, indicates that asking for more family time would be illegitimate, meaning that gender norms are shown in the workplace too. This family represents a more modern gender contract, due to reflections. The second father is satisfied with his role as the breadwinner and he sees the work life dilemma as only being the mothers'. The gender roles still indicate a constraint. Obviously for her, seeing that she complains, but also for him, I would say that I doubt if he has other alternatives. His acceptance simply seems to reflect a rooted gender contract. The first family is simply an example of a family that tries to act against the gender contract, although without success, and the second one is still subject to it. Thus, despite attempts from one family, the outcome and the extensiveness of the gender contract in practice remains equal.

The first UK father argues that it should be easier for fathers to take parental leave:

"but one thing I would change is fathers getting paternity leave..().. ..I would love to be stay at home dad. I just wouldn't be able to do that...I would like to do what the mothers can do and take time off and still have their jobs open for them and still get a decent amount of wages" (UK father 1 , train guard).

This reflects a real preference which is impossible to live accordingly due to determining gender norms. This opinion goes down very well with the rest of the UK families that I have studied in this article. We found that fewer constraints led to more collaboration. However, in practice, this father is constrained in his breadwinner role and thus by the prevailing gender norms. By not providing the families with an institutional framework that give them freer choices, gender norms will remain dominant. Thus, they are still dominating.

"but unfortunately I am the main breadwinner so I can't do that... but I would definitely make it easier for myself to be able to take time off work at important moments of my kids' live... definitely..".

There is a constraint dictating the fathers' role. This father feels the work pressure, too:

Q: "Would you say that sometimes you feel pressure from work?

A: Definitely yeah it's got to the point that I resent my job and but the money that I get for the job and the perks that come with the job".

And his work is a constraint. He adapts his family around work obligations:

"Once the time table comes out in May I would know when I will be working pretty much till December. The only times that change comes from spare shifts" ( UK family 3 - British father 1, train guard in the rail industry). 
This also goes along very well with the looser gender contract and the more collaborative responsibility at home that we have already presented. There are still constraints in practice, however.

For one Danish father, who is an IT-developer, paid work is a constraint for the family. He is expected to work, but seen in retrospective he would have liked to take some leave. No weeks reserved for the father is also a constraint:

Q: "Regarding the discussion about parental leave... Ingrid took leave the first two times, and then you took 4 weeks with Magnus. How have you felt about that division?

A: I would have liked more paternity leave. With the first two there weren't that many options"

This illustrates how leave regulations would impact on behaviour and practices.

"Then I only had an option of the first two weeks. That was all I could get. But with Magnus, the youngest, there was an opportunity for me to take four weeks, and I really wanted to do that" (Danish father 1, IT-developer).

And he also wanted it earlier when the children were young:

Q: "Has your attitude towards that changed along the way, or have you always really wanted that? Would you also have wanted that back then?"

A: "I don't really know. No, I think I also would have wanted it back then with the first child. I have really always been good with little kids, and I've taken care of all three children quite a bit, when they were small. But I'd probably be more on it now. Because I have started to think more about the family now, because I did think a lot about work back then. I didn't speculate about it so much back then, and it wasn't possible to do that. But I'd definitely think about it more today".

It seems that there is a widespread misunderstanding that children are only for the women. There are fathers who want to be with the children, too, and who describes themselves as being good with children. Today, now that the gender contract has been challenged, this father starts to think of alternative strategies and how things could be different. However, changing the practice is now too late, which means that the gender norms have been reproduced.

However, his reflections today go hand in hand with a looser gender contract. The partner has the same job, and she has been working part-time since they had the third child. The second Danish father has taken eight months on leave, but it was due to his work in the navy. However, he says that he would have wanted to have leave, had he worked in a normal job, but he realises that it would not have been that easy to get the leave, at least not for such a long time. Once again we find that there are constraints for real choices, but this father has been 'saved' by being in the navy. This family seems less constrained and thus more liberated from the traditional gender norms:

Q: "When did you realize that you wanted to take paternity leave?

A: It was something that we had discussed. When the new rules for parental leave came out, I thought, wow this is great" (Danish father 2, nutritionist, trained as a chef).

From these examples, we have found that there are fathers who would want paternity leave, however social structures such as gender norms become a barrier. Vice versa, the mothers, too, 
would not mind having their partner's "assistance" at home. In the case of father 1, this is realized too late. The dictating gender norms, which are a result of the story of the gender contract, are too quick to take over the decisions.

\section{Summing up - preferences or constraints?}

The Hungarian families were the most constrained ones. Among the four included countries, they represent the most rooted gender contract; they had the greatest acceptance of the gender order, meaning that they also represented the fewest reflections regarding their gender role constitution. They were the least collaborative ones in paid and unpaid work, meaning that there was least convergence of mothers and fathers in paid and unpaid work. I argued that the acceptance and lack of reflections reflected a rooted gender contract rather than a truly free choice. Latent frustrations between the lines were evidence of a rooted gender contract that was not yet challenged. Some mothers were worried about their work when they were pregnant and in the question of whether the fathers would rather work less or have a higher salary, they would answer according to the situation; he has to work, due to his breadwinning role, since the mother has to take care of the children. This upholds the reproduction of gender norms which results in constraining mothers into unpaid work and fathers into paid work. Thus, their preferences reflect the outer situation - external constraints - and not necessarily a truly genuine personal choice.

In Italy, the frustrations were a bit more outspoken. Thus, the gender contract was a little less rooted, meaning that frustrations reflect an attempt to challenge the rootedness and the dominance of the gender contract. One father also expressed outright a request of wanting to spend more time with his family, but he was constrained by his work. The other father, who saw himself as the breadwinner of the family and who was satisfied with the gender division, had a wife who complained over their household division. Thus, Italy was also constrained about the gender norms - a result of the gender contract that represents a division of mothers and fathers into unpaid and paid work, respectively. Despite some more outspoken frustrations and reflections upon the gender role constitution, Italy was also characterised by a quick acceptance of the gender order. The mothers in the Italian cases were adjusting their careers to their household responsibilities and the breadwinner role of the father. The acceptance of this in Italy also reflects a rooted gender contract and not a free choice where they are liberated from external constraints.

Among the British families, more families were liberated from constraints and they were less constrained. Some of them were collaborating on care and household obligations and on supporting each other's choices of paid and unpaid work. One father was participating in the care work of the twins, and one mother went on with her studies while he was working parttime. This indicates that there is a chance for alternative strategies and genuine choices if both parents liberate themselves from constraints - the traditional gender norms. But some British families were also still constrained. One father very openly argued that he wanted to have paternity leave but he had to work. One mother had to stop working when the child was little, since she could not manage a full-time job alongside having a child. The British families included in this paper represent ambiguous cases, but all in all they are not entirely liberated from external constraints. In contrast to Hungary and Italy, a flexible labour market and a high level of part-time jobs, give the families an opportunity to collaborate if they liberate themselves from traditional gender norms as well, and it gives the mothers an opportunity to remain attached to the labour market, despite their primary care role. The families with collaborative strategies are also unusual examples, it was emphasised. 
One of the Danish fathers was on parental leave for eight months, but this was also emphasised as being unusual, and that it had only been possible to take the leave because of his work in the navy. The other families were quite constrained, too. The difference between Denmark and the way they are constrained by gender norms - the gender contract - in Italy and Hungary, is that the Danish parents have tried to alter the situation and to reflect upon alternatives. However, it does not seem to be realised in practice, which might be due to them being constrained by gender norms, after all. One father would have wanted parental leave, seen in retrospect, but now the traditional gender roles have already been reproduced. Another mother is directly frustrated by the gender division and she tries to alter the situation, however without success, due to his work and attachment to the paid labour market. One family was a breadwinner family, representing a traditional gender role constitution. In this case, she was constrained by his work, and she did not seem to have any other alternatives than being a housekeeper. The latter family type, is, however, very unusual in Denmark. Despite ambiguous cases and reflections upon altering the household division which in itself reflects a more modern contract, Denmark, too, is characterised by constraints. In contrast to other countries, Denmark has more encompassing family policies by which they have greater possibilities to have a more collaborative household strategy. However, it has to be said - which is also the main point of this article - that despite positive family policies with universal and public day-care institutions, it is difficult to combat the story of the gender contract. A status of less family policy regulations, which is the case in Italy and Hungary, makes it even more difficult to live outside the traditional gender contract.

In all families, regardless of country, the gender norms were a constraint for both mothers' and fathers' behaviour. Dictated by gender specific expectations towards fathers' and mothers' positions in the public and private spheres, respectively, the fathers are expected to be breadwinners, to a larger extent than the women, and the mothers are expected to be caregivers.

Lastly, this paper has found that fathers' expectations of being the breadwinner strengthens mothers' position even further into unpaid work, and vice versa, expectations of mothers' role in the private sphere, puts fathers even further in a breadwinner role. It creates a circle that reproduces the gender roles. The gender expectations are also upheld in the labour market, by which the fathers, to a larger extent than mothers, are put under more work pressure, which again contributes to the reproduction of the unequal gender order. Vice versa, labour market expectations towards mothers' and fathers' gender roles also put more pressure on the mother to "go back" and do the care- and household obligations. In order to achieve truly equal opportunities, which is conceptualised as participation in parity by Nancy Fraser, we need to take these barriers - constraints - into account when developing family political strategies. By not overcoming these ruling gender norms, mothers and fathers will not have truly equal opportunities and free access in paid or unpaid work. The gender norms still seem to be a determinant factor regarding mothers' and fathers' behaviour. Ensuring truly equal opportunities and truly equal access in paid and unpaid work for both parents will also ensure equal access in citizenship rights. Mothers being constrained by unpaid work reduces them from participating in citizenship rights, since citizenships rights are still based on paid work. This very crucial point has been emphasised by Ruth Lister (2003). Using the theories of Fraser and Lister, it seems that policies must actively intervene in the private matters of the families in order to influence these inequalising social processes of the genders, where mothers are expected to be caregivers and fathers breadwinners. Evidence has also proven that there seems to be a relationship between active political intervention and mothers' and fathers' behaviour. 
Social research has proven that countries that are characterised by high labour market participation among women, which is the case in Denmark and other Scandinavian countries, also have a relatively higher level of comprehensive family policies (Del Boca and Wetzel, 2007). Denmark has a high level of universal and public based day care facilities by which care has been moved from the family to the state; this supports mothers' labour market attachment. Others have argued that paternity leave that designates some of the leave period only for the fathers, also promotes gender equality in the households (Brighouse and Wright, 2009). As this article has proven, fathers seem constrained by their breadwinner role, as well. Paternity leave would give fathers the incentive to take more parental leave since this kind of policy would overcome the barrier and expectation of only mothers being the caregiver. In this respect, research shows that in Norway and Sweden, where they have introduced paternity leave with a period specifically reserved for the fathers, it has been proven that traditional parenting roles have been challenged (Leira, 1999). Research shows that taking parental leave affects men's thinking about work and family and their subsequent participation in child care (Haas and Hwang, 1999). Now Sweden has two months 'daddy leave'. Thus, such a policy would influence mind sets and perception of gender roles and thus might provide both mothers and fathers with relatively freer opportunities.

\section{References}

Bettio, F. and Plantenga, J (2004). Comparing Care Regimes in Europe, Feminist Economics 10: 85-113

Bittman, M. (ed) and Folbre, N. (ed) 2004. Family Time: The Social Organization of Care. New York, USA: Routledge.

Boje, T.P., and Ejrnæs, A. (2011). Family Policy and Welfare Regimes. In print in H.M. Dahl, Kovalainen, A. \& Keränen, M. (eds.). Care, Europeanization and Gender - Global Complexities. Palgrave

Brighouse, H. and Wright, E., O. (2009). Strong Gender Equalitarianism, In J. C.G, and M.K.M. Gender Equality - the Utopian Project. Verso.

Crompton, R. and Lyonette, C. (2006). Work-life Balance in Europe. Acta Sociologica Vol. 49, No. 4, December, 379-94

Crompton, R., Lewis, S. and Lyonette, C. (2007). Women, Men, Work and Family in Europe. London: Palgrave Press.

Del boca, D. and Wetzel, C. (2007). Social Policies, Labour Markets and Motherhood: a comparative analysis of European Societies. Cambridge University Press.

Esping-Andersen, G. (ed). (2002). Why we need a New Welfare State. Oxford: Oxford University Press.

Esping-Andersen, G. (2009). The Incomplete Revolution. Adapting to Women's New Roles. Polity.

Eurostat Data. Labour force on female employment - full-time and part-time - 2008, 2010. 
Fraser, N. and Honneth, A. (2003). Recognition and Redistribution? A Political Philosphical Exchange. London, Verso

Gash, V. (2008). Constraints or Preferences? Identifying Answers from Part-time Workers' Transition in Denmark, France and United Kingdom". Work, Employment and Society. December 2008, Volume 22, No. 4. Pp. 655-674.

Gash, V. (2008). Sacrificing their Careers for their Families? An Analysis of the Penalty to Motherhood in Europe, CCSR Working Paper, The University of Manchester.

Gershuny, J. and Sullivan, O. (2003). Time Use, Gender and Public Policy Regimes. Social Politics. 10:2.

Gornick, J. C. and Meyers (2003). Families that work New York: Russell Sage Foundation.

Haas, B., Hartel, M., Steiber, N. and Wallace, C. (2006). Household Employment Patterns in an Enlarged European Union. Work, Employment and Society Vol. 20 (4): 751-772

Haas, L., and P. Hwang (1999). Parental leave in Sweden. In P. Moss \& F. DEVEN (Eds.), Parental leave: Progress or pitfall? Research and policy issues in Europe (pp. 45-68). The Hague/Brussels: NIDI/CBGS Publications, Vol. 35

Hakim, C. (1996). Key Issues on Women's Work: female Heterogeneity and polarisation of Women's Employment. London: Atholone Press

Hakim C. (2000). Work-Lifestyle Choices in the Twenty-first Century: Preference Theory. Oxford: Oxford University Press

Hakim, C. (2002). Lifestyle preferences as determinants of women's differentiated labour market careers', Work and Occupations, 29: 428-459, November 2002.

Himmelweit, S. and Sigala, M. (2004). Choice and the Relationship between identities and behavior for mothers with pree-school children: Some implications for policy from a UK study. Journal of Social Policy 33 (3), July 2004; pp. 455-478

Kröger, T. \& and Sipilä, J. (2005). Overstreched. European Families Up against the Demands of Work and Care. Blackwell

Lausten, M., Sjørup, K. (2003). Hvad kvinder og mænd bruger tiden til - om ligestilling i danske familier 03:08. Socialforskningsinstituttet

Leira, A (1999). Cash for Child-Care and Daddy Leave. In Peter Moss \& Fred Deven (ed.), Parental leave: progress or pitfall? Research and policy issues in Europe. NIDI CBGS Publications, Brussels. s 267 - 291

Lister, R. (2003). Citizenship: Feminist perspectives. 2. ed. Washington Square, N.Y.: New York University Press.

Lewis, J., Cambell, M., and Huerta, C. (2008). Patterns of paid and unpaid work in Western 
Europe: gender, commodification, preferences and the implication for policy, Journal of European Social Policy 0958-9287; Vol. 18(1): 21-37

McRae, S. (2003). 'Constraints and Choices in Mothers' Employment Careers: A Consideration of Hakim's Preference Theory'. British Journal of Sociology 54(3): 317-38.

OECD Report: "Babies and Bosses - reconciling work and family life" (2007).

Olsson, Y. (2011). Tracing the Story of the Gender Contract.. Paper presented at $9^{\text {th }}$ Conference of European Sociological Association (ESA), Lissabon 02-05 September 2009 and at Espanet Conference, The Future of the Welfare State, University of Urbino 17-19 September 2009. Submitted to Journal of Family Issues.

Olsson, Y. \& Boje, T. P. (2011). 'Flexibility and Constraints in Work-Family Relations in Europe'. Submitted to Community, Work and Family.

Pascall, G. and Lewis, J. (2004). Emerging Gender Regimes and Policies for Gender Equality in a Wider Europe. Journal of Social Policy (2004) 33:373-394

Pateman, C. (1988). The Sexual Contract. Cambridge: Polity

Pfau-Effinger, B. (2005). Culture and Welfare State Policies: Relections on a Complex Interrelation. Journal of Social Policy, 34, 1. Pp. 1-18

Plantenga, J. and J. Hansen (1999). Assesing equal opportunities in the European Union. International Labour Review, vol. 138, no. 4

Wall, K. (2007). Leave Policy Models and the Articulation of Work and Family in Europe: A Comparative Perspective. In P. Moss and K. Wall (ed.). Internation Review of Leave Policies and Related Research 2007. ERRS No. 80 URN 07/1232

\section{Time budget Studies}

Hungary:

Eurostat Yearbook 2004

Pongrácz, Marietta (2005). Opinions on gender roles. Findings of a International Comparative Study. IN: Ildikó - Pongrácz, Marietta - Tóth István György (Eds.) Chnaging Roles. Report on the Situation of Women and Men in Hungary 2005, 71-85.

Italy and the UK:

OECD family Database LMF11: Time use for work, care and other day-to-day activities. Figures from 2006, last updated June 2010.

Denmark:

Bonke, J. (2002). Tid og Velfærd. The Danish National Center for Social Research

Deding, M. and Lausten, L. (2004). Choosing between his time and her time - Market work and housework among Danish couples. The Danish National Institute of Social Research. Working Paper 4: 2004 
OECD report 2002: Babies and Bosses - reconciling work and family life. Australia, Denmark and Netherlands. Volume 1.

\section{Author}

Yildiz Olsson is a PhD candidate in the Department of Society and Globalisation, Roskilde University, Denmark. Email: yatas@ruc.dk 